POLIIICAL ECONOMY RESEARCH INSIITUTE

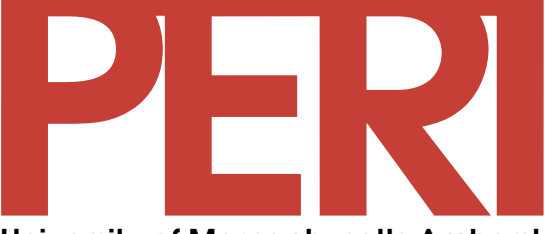

University of Massachusetts Amherst

\title{
Rentier Incomes and Financial Crises: An Empirical Examination of Trends and Cycles in Some OECD Countries
}

\author{
Gerald Epstein \\ Dorothy Power
}

2003

10th floor Thompson Hall University of Massachusetts Amherst, MA, 01003-7510 Telephone: (413) 545-6355 Facsimile: (413) 545-2921

Email:peri@econs.umass.edu Website:

http://www.umass.edu/peri/

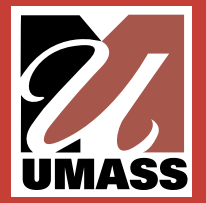




\title{
Rentier Incomes and Financial Crises: An Empirical Examination of Trends and Cycles in Some OECD Countries
}

\author{
Gerald Epstein and Dorothy Power
}

September, 2002; Revised, April, 2003

This Draft: April 9, 2003
Department of Economics and Political Economy Research Institute (PERI)
University of Massachusetts, Amherst
Amherst, MA
USA

The authors thank Erinc Yeldan for many useful comments and suggestions on this paper. We also thank Mathew Abrena for excellent research assistance. Finally, the authors acknowledge the Ford and Rockefeller Foundations for their financial support through their grants to the Political Economy Research Institute (PERI), University of Massachusetts, Amherst. 


\begin{abstract}
We present new estimates of the rentier share of national income for OECD countries for the years between 1960 and 2000. For most countries, the rentier share of income significantly increased during the last several decades, starting in the early 1980's and coinciding with the shift to neo-liberal monetary and financial policies initiated by Margaret Thatcher and Paul Volcker. There is no evidence of a negative correlation between rentier shares and non-financial corporate shares of income. However, rentier shares do decline in those semi-industrialized countries that experienced financial crises. These findings are consistent with the view that financial liberalization has been associated with the increased power of an international rentier class, whose interests are aligned with those of non-financial corporations in the richer countries, but whose interests conflict with rentiers in developing countries that experience financial crises.
\end{abstract}




\section{INTRODUCTION}

Since the late 1970 's, there has been a profound shift in economic policies around the globe. ${ }^{1}$ This policy change from the relatively closed-economy, Keynesian-oriented policies of "embedded liberalism" dominant in the early post-world war II era, to the more internationally open, "free market" neo-liberal policies of the last 20 years or so, has had a massive impact on the world economy and on the people living in it. (Helleiner, 1994; Pieper and Taylor, 1998)

A central aspect of these "Washington Consensus" policies has been the promotion of domestic and international "financial liberalization" and the concomitant explosion of international capital flows. (Pollin, 2001; Ghosh and Chandrasekar, 2001, 2003; Felix, 2001.) The associated surge in financial transactions has also often been associated with currency and financial crises which appear to be ever more frequent and severe. (Akyuz and Boratav, 2001; Boratav and Yeldan, 2000; Crotty and Dymski, 2000; De Palma, 2001; Jomo, K.S. 2001).

A great deal of attention has been focused on the impacts of financial liberalization and crises. But we know much less about the "political economy" of financial liberalization: if financial liberalization is so costly to the general public in developing countries, why do governments keep pursuing it and why do international institutions keep promoting it? More specifically, what are the political forces behind this widespread financial liberalization and its associated economic crises?

Outside of mainstream economists' assumptions about the alleged efficiency of financial liberalization, the most common hypothesis accounting for its rise is that there has been an increase in the power of domestic and global rentiers - wealthy people who get most of their incomes from owning financial assets, rather than working or from owning productive assets (factories, natural resources). (Patnaik, 2003; Crotty and Epstein, 1996; Stiglitz, 2002) This group of rentiers, it is argued, has gained political power, pushed for financial liberalization around the globe, and benefited handsomely from it, thereby enhancing their political power even more. Some versions of the argument suggest that it is the international rentiers -the big banks and insurance companies in the rich countries - that are the prime movers. Others maintain that these groups have linked up in close alliance with rentiers in developing countries. In both cases, observers agree that the IMF, the U.S. Treasury, the Federal Reserve, and other governmental and international institutions have played a central role in articulating and implementing the policy changes promoted by rentier groups.

But, even if one accepts that the rentiers are implicated in this policy change, are they --a minority faction within the capitalist class -- doing this all on their own? What is the relationship between this rentier "class" and other capitalists along this path of financial liberalization? Two views have been promoted. One, similar to the view of political relations in $19^{\text {th }}$ and $20^{\text {th }}$ century Great Britain, is that it is conflict that characterizes this relationship between finance and industry. According to this view, the rise of the rentier class represents a defeat not only for labor, but also for industrial capital. Stressing unity rather than conflict, an opposing view holds

\footnotetext{
${ }^{1}$ This shift in policies has been well documented. See for example, the articles collected in Baker, Epstein and Pollin, 1998, and Ghosh and Chandrasekhar, 2003.
} 
that the rise of the rentiers has gone hand in hand with an alliance between the internationally oriented components of both finance and industry.

More recently, there has been a further evolution of thinking that supports the "unity" view. Some have written of the "financialization" of non-financial corporations - the increasing importance of financial transactions and assets to the profitability of traditionally termed "nonfinancial" firms. This financialization presumably aligns the policy preferences of non-financial corporations with those of rentiers. (Yeldan, 2000; Krippner 2001; Dumenil and Levy, 2001).

Despite this emerging view that financial crises in "emerging markets" are due to the rise in power of a rentier class, there is relatively little empirical work concerning the magnitude of rentier incomes and whether they have actually evolved in a manner that is consistent with these views of rentier power. Have rentier incomes increased in the recent period? If so, has the increase been due to shifts in macroeconomic policy, including financial liberalization? What about non-financial corporate incomes: have they moved inversely to that of rentier incomes, suggesting a conflict of interest, or have they moved in tandem with rentier incomes, suggesting a material basis for an alliance?

In this paper we present new data that attempt to shed light on these issues. More specifically, we present new estimates of rentier incomes in a number of OECD countries, some going back as far as the 1960's. We then compare rentier trends with trends in non-financial corporate incomes. Without rigorous econometric analysis, we cannot, of course, demonstrate causal relationships among these variables. But our results are, nonetheless, highly suggestive.

Our data show that there is a wide variety of experiences across countries in the evolution of rentier shares of income. Despite this variety, however, we find that in many OECD countries, rentier shares began to increase significantly in the late 1970's or early 1980's, just at the beginning of the neo-liberal revolution, as represented by the rise to power of Paul Volcker as Fed Chair in the U.S. and Margaret Thatcher as Prime Minister in the UK. For some countries, this rise in rentier share has continued until the current period. For other countries, however, the share peaked in the early 1990's and has fallen since that time, but is still above the level reached in the 1960's and early 1970's. However, when we include capital gains in our estimates of rentier incomes, for most countries for which we have data, the rise in rentier shares continues until the late 1990's when the stock market crash brings them back down.

An important exception to this generally upward trend (since the early 1980's) of rentier incomes, are semi-industrialized countries that have experienced significant financial crises. These countries have seen a decline in their rentier shares. This suggests that the interest of local rentiers- particularly in the developing world -and those of international rentiers, might not be fully aligned. This is especially the case in periods of financial crisis.

As for non-financial corporate profit shares, we find that, for the most part, there is very little evidence that increases in rentier shares have come at the expense of profit shares accruing to non-financial corporations. This suggests that, in the current period, there is a material basis for unity, rather than rivalry, between industrial and financial capital. This result should be 
juxtaposed to research that shows a decline in labor shares in many OECD countries over this same period (e.g. Blanchard, 1999)

The rest of the paper is organized as follows. In the next section, we define rentier income and briefly describe the data we use in this study. In section III, we present trends on rentier shares and non-financial corporate incomes for OECD countries, going back, in some cases, to 1960. This section excludes data on capital gains. In section IV we present data on rentier shares that include an estimate of capital gains; however, these data only go back to roughly 1980 and should be seen as crude estimates, at best. Section V describes the national and global forces of the last several decades that help explain these shifts in rentier income. In the final section we present conclusions and some suggestions for future research.

\section{RENTIER INCOME DEFINED}

There is no commonly accepted definition of rentier income. Most authors use a definition to denote income that accrues from financial market activity and the ownership of financial assets rather than activity in the "real" sector or the holding of "real" assets such as real estate or capital equipment. For example, Keynes, in his General Theory, refers to the rentier as "the functionless investor," who generates income via his ownership of capital, thus exploiting its "scarcity-value". ${ }^{2}$ For this paper, rentier income will be defined the way Michel Kalecki used the term: it represents the income received by owners of financial firms, plus the return to holders of financial assets generally. (Kalecki, 1990). More specifically, rentier income, as calculated in this paper, consists of the profits earned by firms engaged primarily in financial intermediation plus interest income realized by all non-financial non-government resident units, i.e. the rest of the private economy. In principle, rentier income should include capital gains on financial assets realized by all non-financial non-government resident institutional units. In practice, these data are very hard to find and will not be included in our estimates of section III. Then, in section IV, we present rough estimates of capital gains for some countries. ${ }^{3}$

\section{The Evolution OF RENTIER InCOME SHARES IN OECD COUNTRIES}

\section{Overall Trends of Rentier Income Share}

Table 1 summarizes for each country the trend of rentier income share and compares it to the profit share in the corporate non-financial sector. While there is no single trend of rentier income share among all of the countries, patterns do emerge. The most important pattern is this: for most countries for which we have data, rentier income share was higher in the 1980's and 1990 's than it was in the 1960's and 1970's. These data, then, are consistent with the notion that rentier shares have gone up since the time the neo-liberal period was initiated in the early 1980's.

\footnotetext{
${ }^{2}$ John Maynard Keynes, General Theory of Employment, Interest, and Money, Chapter 24.

${ }^{3}$ See the Appendix for more information on data sources. Please consult Power, Epstein and Abrena (2003) for detailed information on data sources and definitions.
} 
For example, between the decades of the '60's and '70's on the one hand, and the 80's and 90 's, on the other, the rentier share in the UK went up by $143 \%$, in the U.S. by $92 \%$, in Korea by $112 \%$ and in France by $155 \%$. (See the final column in table 1). Only three out of the seventeen countries for which we have sufficient data - Iceland, Spain, and Sweden experienced a decline in rentier share over those decades.

Table 1 also presents data on the non-financial profits share for many of the countries in our sample. The final column of table 1 shows that out of the twelve countries for which we have sufficient data, four experienced a decline in non-financial corporate profit share over this period. The rest of the countries witnessed an increase in non-financial shares, but these increases were generally much smaller, in percentage terms, than the increases in rentier shares.

So the overall message in table 1 is that, between the 1960's and 1970's, on the one hand and the 1980's and 1990's on the other, rentier shares of national income made a dramatic increase in most of the OECD countries, while non-financial profit shares generally either made a modest increase or declined. So, if the 1980's and 1990's were the decades of the rentier, in most countries the non-financial corporations did not have to foot the bill.

These general increases in rentier shares were not constant in most countries, by any means. An inspection of the time trends of rentier shares and non-financial corporate profit shares show a fairly large degree of variability in most countries. (Power, Epstein, and Abrena, 2003). Because of space limitations, we present time trends for only a few of the countries here.

Figures $1-7$ show the evolution of the rentier income share, its components (where available) and the share of non-financial corporate profits in national income for six of the wealthier OECD countries: France, Germany, Japan, Netherlands, the UK, and the US. ${ }^{4}$ For most of these countries, rentier shares of income increase in the 1980's. For some, like the U.S. and U.K, the share increased until the mid-1990's and then began to fall. For others, such as France, the share continued to rise throughout the period.

These graphs also show profit shares for non-financial corporations. The data indicate that there is no clear negative relationship between non-financial corporate income share and rentier income share. While these two shares fluctuate in inverse directions in some periods for some countries, overall there does not appear to be a negative relationship between them. Hence, the data suggest that when rentier income shares increase, they do not come at the expense of non-financial corporate shares. Hence, on the basis of this admittedly preliminary evaluation of the data, there appears to be no material basis evident in these data for a political division between rentiers and non-financial capitalists in these particular countries. ${ }^{5}$

Figures 8 - 10 present data on several of the semi-industrialized countries in our sample: Korea, Mexico and Turkey. These are all countries that implemented a policy of financial liberalization in the 1980's and/or 1990s, and then experienced financial crises. In all three cases, rentier shares increased following periods of financial liberalization; but when financial crisis

\footnotetext{
${ }^{4}$ Because of space considerations, not all countries' graphs are presented.

${ }^{5}$ Of course, this observation is very speculative and needs to be confirmed by more rigorous statistical methods.
} 
struck, rentier shares fell, and, in some cases, even plummeted. Hence, the owners of financial assets and institutions were not immune to the costs of financial crisis.

\section{RENTIER InCOME SHARE InCLUding CAPITAl Gains on FinanCial ASSETS}

This section presents estimates of rentier share including capital gains. It is important to make an effort to include capital gains because, especially in the 1990's, these gains potentially became a very large component of returns from holding financial assets. However, high quality capital gains data are very difficult to find. As a result, we had to estimate capital gains. For most of the countries for which data were available, we estimated capital gains by estimating the increase in the value of total financial assets over each year and then subtracted an estimate of the net issues of new investments in that year. ${ }^{6}$

In order to check the robustness of our method, we calculated capital gains on financial assets in the United States (which has relatively good capital gains data). Figure 11 shows capital gains on financial assets for the United States calculated three different ways: one using the method and data sources we used for all countries; a second using the method applied to other countries but using flow of funds data; and the third using estimates of holding period capital gains data from the flow of funds accounts. It is clear from the figure that while the computation given by the formula tends to understate capital gains on financial assets, the trend is very much the same using the two methods. If the data for the United States is comparable to the others, then the data we are presenting for the other countries might be underestimates of their capital gains.

Figure 12 shows a comparison of the three estimates of rentier income share based on the three approaches to computing capital gains on financial assets for the United States. Here, and in Table 2 below we estimate rentier shares as rentier income defined previously plus capital gains divided (in the denominator) by GDP plus capital gains. The trends of all three series are very similar.

\section{Overall Trends in Rentier Income Share Including Capital Gains on Financial Assets}

Table 2 shows the rentier income share data including capital gains on financial assets. We have capital gains estimates for fewer countries and for a shorter time period than reported in Table 1. Recall that, in the case of the U.S., for example, rentier income share fell in the late 1990's when capital gains were excluded from the data (see, for example, Figure 7). However, when capital gains estimates are included, the rentier share continues to increase into the late 1990 's. This is to be expected, given the massive stock market boom that occurred in many OECD countries at that time. For the most part, then, these data reinforce the conclusion drawn earlier that rentier shares increased in many OECD countries, starting in the early 1980's and going into the late 1990 's.

\footnotetext{
${ }^{6}$ See the appendix and Power, Epstein and Abrena (2003) for a discussion of the methods and sources.
} 


\section{The CAUSES ANd Implications Of INCREASES In Rentier InCOMES}

These increases in rentier incomes in the 1980's and 1990's are undoubtedly a complex phenomenon, having multiple and idiosyncratic causes. However, there are some common structural changes that we believe played an important role. ${ }^{7}$ First, the shift to anti-inflation focused monetary policy following the example of Margaret Thatcher in the late 1970's and Paul Volcker of the U.S. Federal Reserve in 1981, led to much lower inflation and higher real interest rates in many parts of the world, including the OECD countries. Lower inflation rates and higher real interest rates, in turn, played a major role in increasing the share of income accruing to those holding financial assets.

Table 3 presents data on inflation rates and real interest rates for our sample of countries from the 1960's until the late 1990's. The table clearly indicates a number of stark, though well known facts: first, inflation rates for most countries in our group were higher in the 1970's than they were in the 1980's. Indeed, for most countries, they were even higher in the 1960's than in the 1990's. Hence, the 1980's and 1990's were the decades of disinflation.

As a related matter, table 3 also indicates that real interest rates - measured in the table as nominal short-term interest rates minus the rate of inflation - were often negative in the 1970's, but increased significantly in the 1980's and 1990's. The final column in Table 3 shows that in virtually all the countries in the sample, real interest rates went up by 2-19 percentage points between the 1960's and 70's on the one hand, and the 1980's and 90's on the other.

The main exceptions to these general trends were several semi-industrialized economies, including Turkey and Mexico as well as Eastern European countries such as Poland and Hungary, which had rather different experiences. Several of these countries experienced increases in inflation rates and decreases in real interest rates over these decades.

These countries, too, confronted disinflationary monetary policies, though later in the period than the industrialized economies of the OECD.

Monetary policy dominated by inflation targets - formal or informal - often conducted by "independent" central banks, played a crucial role in bringing down inflation and raising real interest rates. This, in turn, was one of the central planks of the neo-liberal approach to macroeconomic policy that characterized the period of the 1980's and 1990's (e.g. Epstein, 2001). These increases in real interest rates and reductions in inflation both contributed to the rise of rentier shares in these economies.

A second important component of neo-liberalism, and one which undoubtedly contributed to the rise of rentier shares, was the financial liberalization, both domestic and external, that characterized this period. Increases in financial liberalization raised rentier shares in several ways. First, financial liberalization allowed banks and other lenders to raise nominal interest rates. This in turn contributed to increase in real interest rates as reflected in Table 3. Second, it allowed financial firms to innovate and expand, thereby increasing products and profits. Third, financial liberalization and liberalization of the capital account created more

\footnotetext{
${ }^{7}$ Three are a large number of good discussions of these issues. See, for example, Pollin, 2003; Yeldan, 2000; Ghosh and Chandrasekhar, 2002; Crotty, 2002; Epstein, 1981, 2001.
} 
financial instability, and thereby, created the need for economic actors to purchase more financial products and create more profits for finance. This process represented a kind of virtuous circle of liberalization, instability, more financial activity, more profits for financial firms. These firms often lobbied for more liberalization which then led to a further running of the cycle.

A third component was also important. External financial liberalization - and in particular the elimination of capital controls, first in the wealthier countries, and then in the poorer countries - offered significantly more profit making opportunities for financial firms. By investing abroad, and being able to freely repatriate those returns, financial firms in the OECD countries found many more opportunities for profitable investments. Of course, many of the emerging markets in which they invested, eventually proved problematic. But IMF and U.S. treasury bailouts often helped to underwrite rentier income even in these difficult circumstances.

A fourth factor worked against increases in rentier shares, as we measure it. Austerity focused fiscal policy led to declines in the relative size of budget deficits in many countries (the Maasricht targets are one example of this). This reduction in government debt reduced the amount of interest payments from governments to rentiers, thereby reducing the rentier share.

As we have seen, in most countries increases in rentier shares have not been associated with declines in non-financial corporate profit shares. Thus, some other group must be losing out. Evidence suggests that in most cases, that group is labor. Important papers by Diwan (2001) and Harrison (2002) show that labor shares have declined as a result of financial crises (Diwan), and as a result of the dismantling of capital controls (Harrison). They both also show a widespread downward trend in labor shares in many countries even after controlling for these and other variables. Hypotheses to explain these trend declines include: changes in norms about unions; financial liberalization; increasing frequency of economic crisis; and increased international competition through globalization. Much work remains to be done to sort out the relative importance of these factors.

Whatever the cause, in many countries, declines in labor shares are an important factor allowing for widespread increases in rentier shares, as shown in Tables 1 and Table 2.

\section{CONCLUSIONS AND FUtURE RESEARCH}

These data have indicated that rentier shares in many countries have increased since the early 1980's. These trends are certainly consistent with the argument that rentiers have benefited from recent policy changes, notably the policies of financial liberalization and austerity oriented macroeconomic policy. Moreover, our data suggest that these increases have NOT, in general, come at the expense of non-financial corporate profit shares. This, in turn, has two implications. The first is that other sectors in society, most notably labor, have seen their shares shrink over this period. And second, the income trends are consistent with the creation and preservation of political alliances between finance and industry in many of these countries. However, in the case of semi-industrialized economies experiencing financial crises, rentier income shares fell 
sharply, suggesting that in these countries, rentier groups may soon experience "liberalization fatigue".

Of course, there is much more work to be done in this area. For one thing, it is important to look more rigorously at the determinants of these trends in rentier shares: how much is due to changes in macroeconomic factors, such as inflation rates, interest rates and economic growth, and how much is due to other policy factors, such as financial liberalization? Second, it would be very useful to look more carefully at the financialization of non-financial firms, even though doing so presents enormous data problems (Crotty, 2002; Krippner, 2002). Third, we would like to find data on more emerging market countries. This too presents considerable data challenges.

Most importantly, we need to consider much more carefully the relationship between trends in income shares and the political economy of financial liberalization. To this end, using data on rentier shares and the income shares of other groups in detailed case studies of countries and episodes of financial liberalization would be of enormous help in enhancing our understanding the political economy of financial liberalization in the world economy. 


\section{Table 1: Rentier Income Share Not InCluding Capital Gains on Financial AsSets in Some OECD Countries, 1960-2000}

\begin{tabular}{|c|c|c|c|c|c|c|c|c|c|c|c|c|}
\hline \multirow[t]{2}{*}{ Country } & \multicolumn{2}{|c|}{ Years Reported } & \multicolumn{2}{|c|}{$\begin{array}{c}\text { Average Decade } \\
\text { Share 1960s } \\
\text { (Percent of GDP) }\end{array}$} & \multicolumn{2}{|c|}{$\begin{array}{c}\text { Average Decade } \\
\text { Share 1970s } \\
\text { (Percent of GDP) }\end{array}$} & \multicolumn{2}{|c|}{$\begin{array}{c}\text { Average Decade } \\
\text { Share 1980s } \\
\text { (Percent of GDP) }\end{array}$} & \multicolumn{2}{|c|}{$\begin{array}{c}\text { Average Decade } \\
\text { Share 1990s (Percent } \\
\text { of GDP) }\end{array}$} & \multicolumn{2}{|c|}{$\begin{array}{c}\text { Percentage Change } \\
\text { over the Period } \\
1960 \mathrm{~s} / 1970 \mathrm{~s} \text { and } \\
1980 \mathrm{~s} / 1990 \mathrm{~s} \\
\end{array}$} \\
\hline & $\begin{array}{c}\text { Rentier } \\
\text { income } \\
\text { share }\end{array}$ & $\begin{array}{c}\text { Non- } \\
\text { Financial } \\
\text { Sector } \\
\text { Profit } \\
\text { Share } \\
\end{array}$ & $\begin{array}{l}\text { Rentier } \\
\text { income } \\
\text { share }\end{array}$ & $\begin{array}{c}\text { Non- } \\
\text { Financial } \\
\text { Sector } \\
\text { Profit } \\
\text { Share } \\
\end{array}$ & $\begin{array}{l}\text { Rentier } \\
\text { income } \\
\text { share }\end{array}$ & $\begin{array}{c}\text { Non- } \\
\text { Financial } \\
\text { Sector } \\
\text { Profit } \\
\text { Share } \\
\end{array}$ & $\begin{array}{c}\text { Rentier } \\
\text { income } \\
\text { share }\end{array}$ & $\begin{array}{c}\text { Non- } \\
\text { Financial } \\
\text { Sector } \\
\text { Profit } \\
\text { Share } \\
\end{array}$ & $\begin{array}{c}\text { Rentier } \\
\text { income } \\
\text { share }\end{array}$ & $\begin{array}{c}\text { Non- } \\
\text { Financial } \\
\text { Sector } \\
\text { Profit } \\
\text { Share } \\
\end{array}$ & $\begin{array}{c}\text { Rentier } \\
\text { income } \\
\text { share }\end{array}$ & $\begin{array}{c}\text { Non- } \\
\text { Financial } \\
\text { Sector } \\
\text { Profit } \\
\text { Share }\end{array}$ \\
\hline AUSTRALIA & $1969-1998$ & $1969-1995$ & 6.67 & 12.66 & 7.92 & 8.10 & 14.50 & 5.24 & 12.97 & 7.91 & $88.4 \%$ & -26.76 \\
\hline AUSTRIA & 1987-1999 & 1995-1999 & --- & --- & --- & --- & 8.53 & --- & 6.34 & 13.49 & --- & --- \\
\hline BELGIUM & 1970-1999 & 1970-1999 & --- & --- & 11.69 & 11.66 & 21.81 & 12.92 & 21.28 & 14.66 & $84.4 \%$ & 18.30 \\
\hline CANADA & 1982-1999 & --- & --- & --- & --- & --- & 12.22 & --- & 13.15 & --- & --- & --- \\
\hline CZECH REPUBLIC & 1993-1999 & --- & --- & --- & --- & --- & --- & --- & -0.64 & --- & --- & --- \\
\hline DENMARK & 1970-1999 & 1981-1999 & --- & --- & 4.94 & --- & 11.62 & 6.45 & 11.75 & 16.05 & $136.7 \%$ & --- \\
\hline FINLAND & $1960-2000$ & $1960-2000$ & 5.61 & 14.28 & 6.04 & 7.37 & 6.58 & 6.72 & 8.75 & 10.56 & $31.5 \%$ & -19.33 \\
\hline FRANCE & 1970-1999 & 1970-1995 & --- & --- & 6.24 & 6.39 & 10.62 & 5.97 & 21.19 & 11.07 & $155.0 \%$ & 23.25 \\
\hline GERMANY & 1960-1999 & 1960-1999 & 2.98 & 16.23 & 5.02 & 12.09 & 7.83 & 9.80 & 7.43 & 11.16 & $90.9 \%$ & -26.02 \\
\hline GREECE & $1989-1998$ & --- & --- & --- & --- & --- & 0.29 & --- & 0.59 & --- & --- & --- \\
\hline HUNGARY & 1994-1999 & --- & --- & --- & --- & --- & --- & --- & 0.24 & --- & --- & --- \\
\hline ICELAND & 1979-1999 & --- & --- & --- & 0.65 & --- & 0.34 & --- & 0.34 & --- & $-47.1 \%$ & --- \\
\hline IRELAND & 1995-1998 & --- & --- & --- & --- & --- & --- & --- & 2.72 & --- & --- & --- \\
\hline ITALY & 1980-1999 & 1980-1999 & --- & --- & --- & --- & 18.77 & 11.68 & 18.08 & 16.12 & --- & --- \\
\hline JAPAN & 1960-1999 & 1960-1998 & 9.00 & 11.96 & 12.30 & 9.02 & 14.27 & 9.91 & 11.22 & 8.25 & $19.7 \%$ & -12.54 \\
\hline KOREA & 1975-1999 & $1975-1995$ & --- & --- & 4.69 & 7.32 & 8.64 & 7.93 & 11.28 & 8.23 & $112.1 \%$ & 9.90 \\
\hline LUXEMBOURG & 1979-1999 & 1979-1999 & --- & --- & 6.14 & 6.14 & 6.43 & 6.43 & 12.41 & 12.41 & $53.3 \%$ & 53.31 \\
\hline MEXICO & 1989-1999 & 1993-1999 & --- & --- & --- & --- & 1.52 & --- & 6.74 & 23.92 & --- & --- \\
\hline NETHERLANDS & 1977-1999 & 1977-1999 & --- & --- & 13.47 & 9.86 & 18.69 & 13.06 & 20.97 & 15.33 & $47.2 \%$ & 43.90 \\
\hline NEW ZEALAND & 1990-1999 & --- & --- & --- & --- & --- & --- & --- & 7.71 & --- & --- & --- \\
\hline NORWAY & $1978-2000$ & 1978-1999 & --- & --- & 6.03 & 10.74 & 10.45 & 12.44 & 9.56 & 15.20 & $65.9 \%$ & 29.31 \\
\hline POLAND & 1993-1999 & --- & --- & --- & --- & --- & --- & --- & 0.63 & --- & --- & --- \\
\hline PORTUGAL & 1986-1998 & 1986-1998 & --- & --- & --- & --- & 15.92 & 14.90 & 16.90 & 11.87 & --- & --- \\
\hline SPAIN & 1979-1999 & 1985-1999 & --- & --- & 14.47 & --- & 12.53 & 8.70 & 13.21 & 9.22 & $-11.0 \%$ & --- \\
\hline SWEDEN & 1979-1998 & 1980-1999 & --- & --- & 13.61 & --- & 12.34 & 2.95 & 12.30 & 5.51 & $-9.5 \%$ & --- \\
\hline SWITZERLAND & 1979-1999 & 1990-1995 & --- & --- & 5.61 & --- & 7.34 & --- & 9.14 & 7.34 & $46.8 \%$ & --- \\
\hline TURKEY & 1983-1999 & --- & --- & --- & --- & --- & 0.70 & --- & 1.19 & --- & --- & --- \\
\hline UK & $1968-2000$ & $1968-2000$ & 3.97 & 14.82 & 6.33 & 13.45 & 10.85 & 15.83 & 14.16 & 15.95 & $143.0 \%$ & 16.19 \\
\hline US & 1960-1999 & 1960-1999 & 14.81 & 11.31 & 22.47 & 10.65 & 38.26 & 12.18 & 33.49 & 9.97 & $92.4 \%$ & 0.89 \\
\hline
\end{tabular}

Source: See Power, Epstein and Abrena (2003). 
TABLE 2: RENTIER INCOME SHARE InCluding CAPITAL GaINS ON

FinANCIAL ASSETS in SOME OECD COUNTRIES

\begin{tabular}{|c|c|c|c|c|}
\hline Country & $\begin{array}{c}\text { Years } \\
\text { Reported }\end{array}$ & $\begin{array}{c}\text { Decade } \\
\text { Average } \\
\text { 1980s } \\
\end{array}$ & $\begin{array}{c}\text { Decade } \\
\text { Average } \\
1990 s \\
\end{array}$ & $\begin{array}{c}\text { Percentage Change } \\
\text { over the Period 1980s } \\
\text { and 1990s }\end{array}$ \\
\hline AUSTRALIA & $1989-1998$ & 35.02 & 33.81 & $-3.44 \%$ \\
\hline AUSTRIA & --- & --- & --- & --- \\
\hline BELGIUM & $1981-1999$ & 46.69 & 47.08 & $0.83 \%$ \\
\hline CANADA & $1982-1998$ & 34.16 & 34.66 & $1.46 \%$ \\
\hline CZECH REPUBLIC & --- & --- & --- & --- \\
\hline DENMARK & $1995-1999$ & --- & 42.30 & --- \\
\hline FINLAND & --- & --- & --- & --- \\
\hline FRANCE & $1981-1997$ & 37.73 & 26.53 & $-29.68 \%$ \\
\hline GERMANY & $1981-1996$ & 22.51 & 25.86 & $14.87 \%$ \\
\hline GREECE & --- & --- & --- & --- \\
\hline HUNGARY & --- & --- & --- & --- \\
\hline ICELAND & --- & --- & --- & --- \\
\hline IRELAND & --- & --- & --- & --- \\
\hline ITALY & $1992-1999$ & --- & 39.69 & --- \\
\hline JAPAN & 1990 - 1991 & 32.21 & 2.80 & $-91.32 \%$ \\
\hline KOREA & $1981-1998$ & 41.40 & 72.14 & $74.25 \%$ \\
\hline LUXEMBOURG & --- & --- & --- & --- \\
\hline MEXICO & $1989-1999$ & --- & 98.95 & --- \\
\hline NETHERLANDS & --- & --- & --- & --- \\
\hline NEW ZEALAND & --- & --- & --- & --- \\
\hline NORWAY & $1981-1995$ & 37.22 & 14.25 & $-61.71 \%$ \\
\hline POLAND & --- & --- & --- & --- \\
\hline PORTUGAL & $1996-1998$ & --- & 48.77 & --- \\
\hline SPAIN & $1981-1998$ & 39.28 & 42.68 & $8.63 \%$ \\
\hline SWEDEN & $1991-1998$ & --- & 37.54 & --- \\
\hline SWITZERLAND & --- & --- & --- & --- \\
\hline TURKEY & --- & --- & --- & --- \\
\hline UK & $1981-1997$ & 48.96 & 46.24 & $-5.55 \%$ \\
\hline US & $1981-1999$ & 58.94 & 59.19 & $0.43 \%$ \\
\hline
\end{tabular}

Source: See Power, Epstein and Abrena (2003) 
TABLE 3: INFLATION RATES AND REAL INTEREST RATES IN SOME OECD COUNTRIES

Change (Percentage

Decade Average Rate Decade Average Decade Average Rate Decade Average Rate Points) over the Period 1960s (Percent of Rate 1970s (Percent 1980s (Percent of $\quad 1990 s$ (Percent of $\quad 1960 \mathrm{~s} / 1970 \mathrm{~s}$ and

\begin{tabular}{|c|c|c|c|c|c|c|c|c|c|c|c|c|}
\hline \multirow[t]{2}{*}{ Country } & \multicolumn{2}{|c|}{ Years Reported } & \multicolumn{2}{|c|}{ GDP) } & \multicolumn{2}{|c|}{ of GDP) } & \multicolumn{2}{|c|}{ GDP) } & \multicolumn{2}{|c|}{ GDP) } & \multicolumn{2}{|c|}{$1980 \mathrm{~s} / 1990 \mathrm{~s}$} \\
\hline & $\begin{array}{c}\text { Inflation } \\
\text { Rate } \\
\end{array}$ & $\begin{array}{c}\text { Real } \\
\text { Interest } \\
\text { Rate } \\
\end{array}$ & $\begin{array}{c}\text { Inflation } \\
\text { Rate }\end{array}$ & $\begin{array}{c}\text { Real } \\
\text { Interest } \\
\text { Rate }\end{array}$ & $\begin{array}{c}\text { Inflation } \\
\text { Rate }\end{array}$ & $\begin{array}{c}\text { Real } \\
\text { Interest } \\
\text { Rate }\end{array}$ & $\begin{array}{c}\text { Inflation } \\
\text { Rate }\end{array}$ & $\begin{array}{c}\text { Real } \\
\text { Interest } \\
\text { Rate }\end{array}$ & $\begin{array}{c}\text { Inflation } \\
\text { Rate }\end{array}$ & $\begin{array}{c}\text { Real } \\
\text { Interest } \\
\text { Rate }\end{array}$ & $\begin{array}{c}\text { Inflation } \\
\text { Rate }\end{array}$ & $\begin{array}{c}\text { Real } \\
\text { Interest } \\
\text { Rate }\end{array}$ \\
\hline AUSTRALIA & $1960-2000$ & $1968-2000$ & 2.46 & 2.57 & 9.83 & -1.14 & 8.41 & 6.07 & 2.68 & 4.46 & -0.60 & 4.54 \\
\hline AUSTRIA & $1960-2000$ & $1965-2000$ & 3.34 & 1.19 & 6.10 & -0.20 & 3.84 & 3.18 & 2.40 & 3.27 & -1.60 & 2.73 \\
\hline BELGIUM & $1960-2000$ & $1960-2000$ & 2.66 & 1.87 & 7.13 & 0.38 & 4.90 & 5.63 & 2.18 & 3.70 & -1.36 & 3.54 \\
\hline CANADA & $1960-2000$ & $1960-2000$ & 2.53 & 2.65 & 7.38 & 0.66 & 6.51 & 4.47 & 2.25 & 4.06 & -0.58 & 2.61 \\
\hline CZECH REPUBLIC & $1994-2000$ & $1993-2000$ & --- & --- & --- & --- & --- & --- & 7.59 & 4.31 & --- & --- \\
\hline DENMARK & $1960-2000$ & $1960-2000$ & 5.34 & 2.41 & 9.29 & 4.37 & 6.91 & 7.75 & 2.18 & 6.07 & -2.77 & 3.53 \\
\hline FINLAND & $1960-2000$ & $1970-2000$ & 5.05 & --- & 10.41 & -0.49 & 7.32 & 5.23 & 2.25 & 4.75 & -2.94 & 5.48 \\
\hline FRANCE & $1960-2000$ & $1970-2000$ & 3.87 & --- & 8.91 & -0.28 & 7.38 & 3.62 & 1.87 & 4.37 & -1.76 & 4.27 \\
\hline GERMANY & $1960-2000$ & $1960-2000$ & 2.40 & 2.19 & 4.88 & 1.93 & 2.91 & 3.88 & 2.29 & 3.35 & -1.04 & 1.55 \\
\hline GREECE & $1960-2000$ & $1960-2000$ & 1.95 & 6.55 & 12.30 & -1.27 & 19.49 & -1.00 & 10.39 & 5.42 & 7.82 & -0.43 \\
\hline HUNGARY & $1973-2000$ & $1970-2000$ & --- & --- & 4.54 & -0.18 & 8.96 & -4.19 & 21.04 & -0.92 & 10.46 & -2.37 \\
\hline ICELAND & $1960-2000$ & $1973-2000$ & 10.63 & --- & 29.43 & -15.30 & 39.17 & -11.67 & 4.34 & 2.00 & 1.73 & 10.46 \\
\hline IRELAND & $1960-2000$ & $1975-2000$ & 4.00 & --- & 12.76 & -4.40 & 9.34 & 3.30 & 2.61 & 4.82 & -2.41 & 8.46 \\
\hline ITALY & $1960-2000$ & $1971-2000$ & 3.63 & --- & 12.33 & -2.50 & 11.20 & 4.29 & 3.98 & 4.72 & -0.39 & 7.00 \\
\hline JAPAN & $1960-2000$ & $1966-2000$ & 5.35 & 2.05 & 9.09 & -1.42 & 2.53 & 3.97 & 1.04 & 2.35 & -5.44 & 2.84 \\
\hline KOREA & $1967-2000$ & $1974-2000$ & 11.32 & --- & 15.22 & 4.02 & 8.41 & 7.85 & 5.41 & 6.95 & -6.36 & 3.38 \\
\hline LUXEMBOURG & $1960-2000$ & $1960-2000$ & 2.17 & 2.36 & 6.50 & 1.01 & 4.72 & 5.81 & 2.32 & 3.56 & -0.82 & 3.00 \\
\hline MEXICO & $1960-2000$ & $1977-2000$ & 2.00 & --- & 14.76 & -9.42 & 69.27 & -18.30 & 19.41 & -1.74 & 35.96 & -0.61 \\
\hline NETHERLANDS & $1960-2000$ & $1960-2000$ & 4.12 & 0.25 & 7.06 & -0.45 & 2.87 & 4.33 & 2.45 & 3.08 & -2.93 & 3.80 \\
\hline NEW ZEALAND & $1960-2000$ & $1974-2000$ & 3.23 & --- & 11.46 & -2.73 & 12.04 & 4.68 & 2.09 & 5.93 & -0.28 & 8.04 \\
\hline NORWAY & $1960-2000$ & $1972-2000$ & 3.49 & --- & 8.38 & -0.53 & 8.34 & 4.46 & 2.50 & 5.04 & -0.51 & 5.28 \\
\hline POLAND & $1971-2000$ & $1989-2000$ & --- & --- & 4.07 & --- & 53.39 & -143.24 & 76.42 & -48.23 & 60.83 & --- \\
\hline PORTUGAL & $1960-2000$ & $1966-2000$ & 4.06 & -2.67 & 17.12 & -8.87 & 17.64 & 0.34 & 5.71 & 4.20 & 1.09 & 8.04 \\
\hline SPAIN & $1960-2000$ & $1977-2000$ & 5.77 & --- & 14.39 & -3.78 & 10.25 & 4.78 & 4.15 & 4.51 & -2.88 & 8.42 \\
\hline SWEDEN & $1960-2000$ & $1963-2000$ & 3.77 & 1.71 & 8.57 & -2.14 & 7.94 & 3.72 & 3.07 & 4.54 & -0.67 & 4.35 \\
\hline SWITZERLAND & $1960-2000$ & $1974-2000$ & 3.12 & --- & 4.98 & -0.55 & 3.24 & 1.93 & 2.30 & 1.95 & -1.28 & 2.49 \\
\hline TURKEY & $1960-2000$ & $1973-2000$ & 0.00 & --- & 23.33 & -27.43 & 51.74 & -11.38 & 75.21 & -4.91 & 51.81 & 19.28 \\
\hline UK & $1960-2000$ & $1960-2000$ & 3.53 & 2.84 & 12.63 & -2.37 & 7.43 & 4.03 & 3.64 & 4.07 & -2.54 & 3.82 \\
\hline US & $1960-2000$ & $1960-2000$ & 2.33 & 2.26 & 7.10 & 0.14 & 5.55 & 4.69 & 3.04 & 2.99 & -0.42 & 2.64 \\
\hline
\end{tabular}

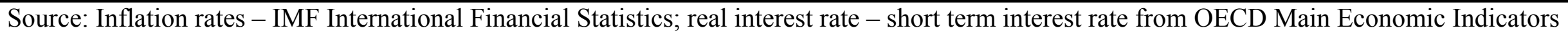
(real interest rate $=$ short term interest rate - inflation $)$

Note: Figures for 2000 are included in calculations for 1990 


\section{FigURES}

Figure 1: Components of Rentier Income Share and Non-Financial Sector Profit Share: France 1970-2000

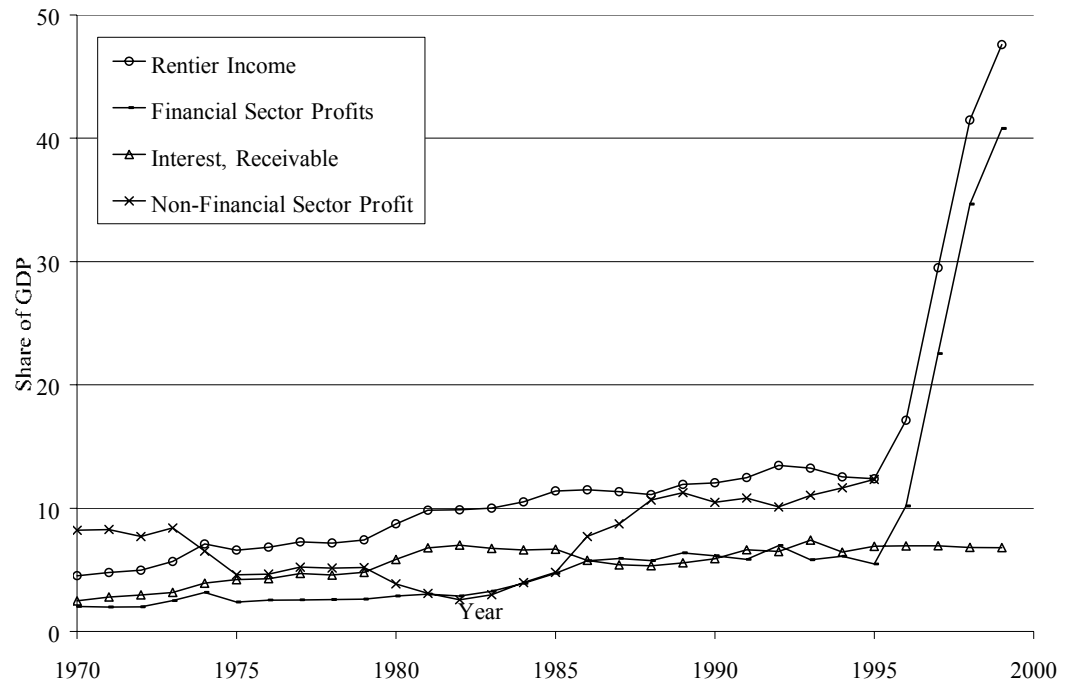

Figure 2: Components of Rentier Income Share and Non-Financial Sector Profit Share: Germany 1960-2000

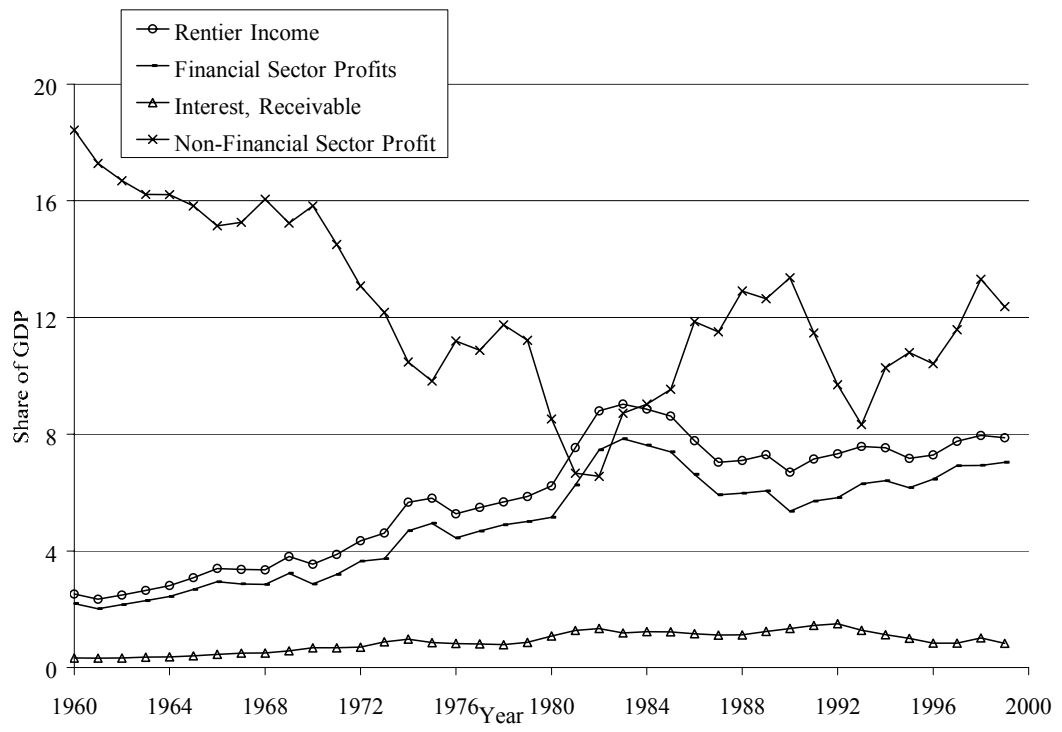


Figure 3: Components of Rentier Income Share and Non-Financial Sector Profit Share: Japan 1960-2000

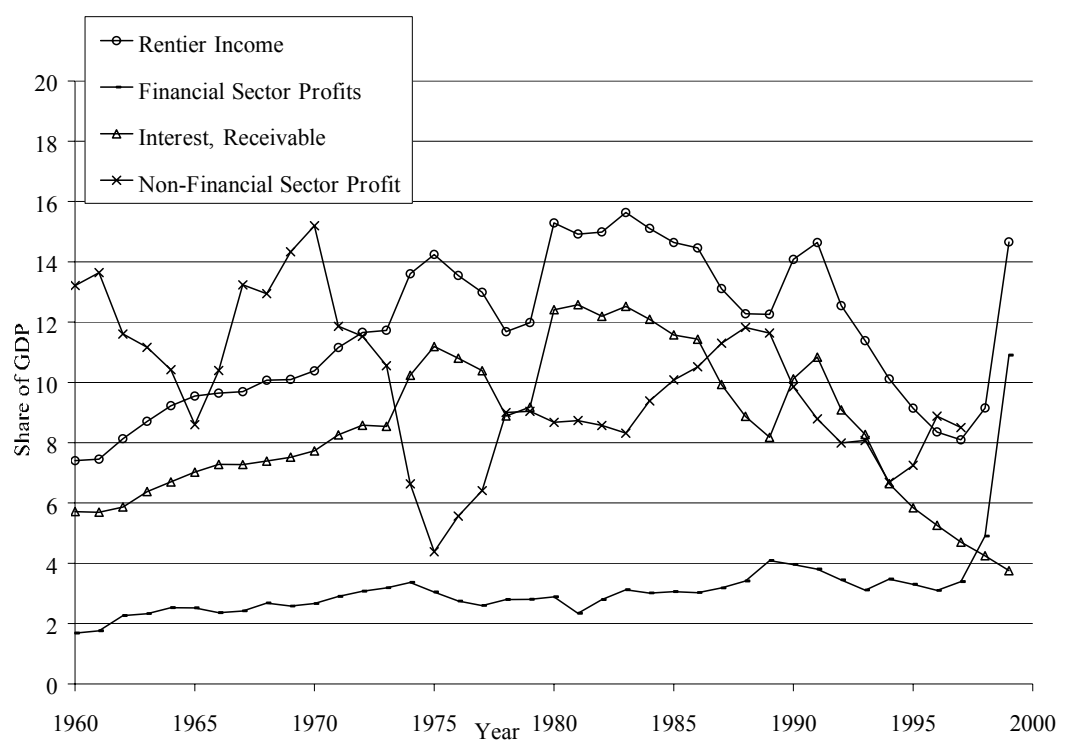

Figure 4: Components of Rentier Income Share and Non-Financial Sector Profit Share: Netherlands 1977-1999

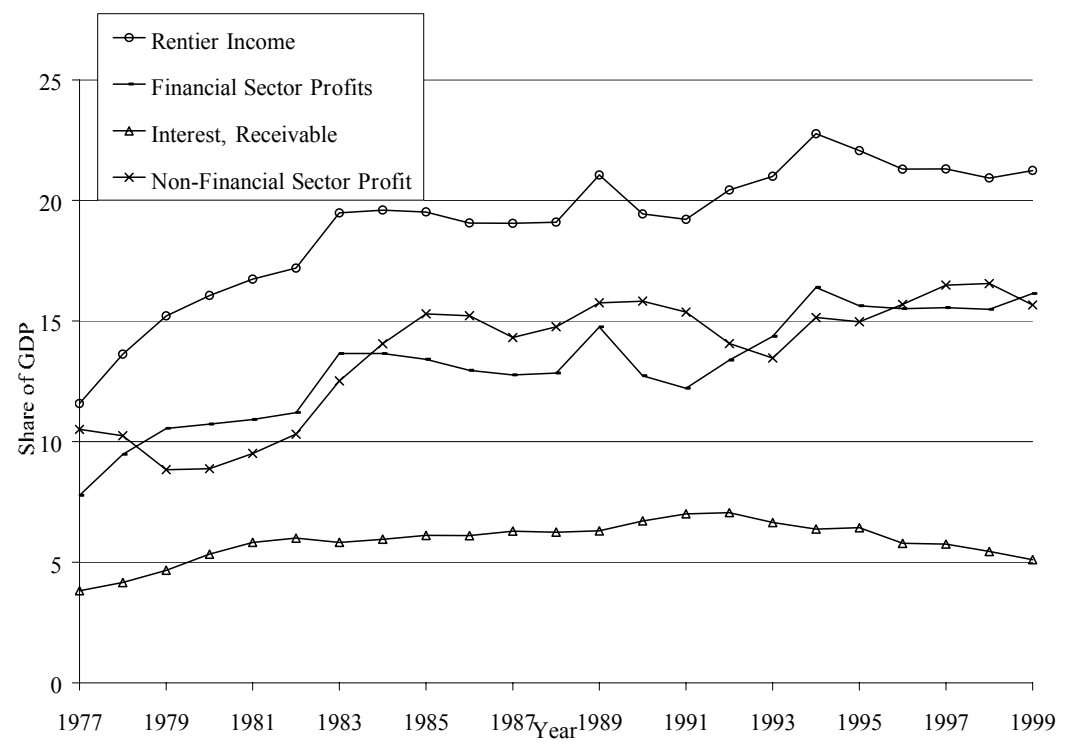


Figure 5: Components of Rentier Income Share and Non-Financial Sector Profit Share: Sweden 1979-1999

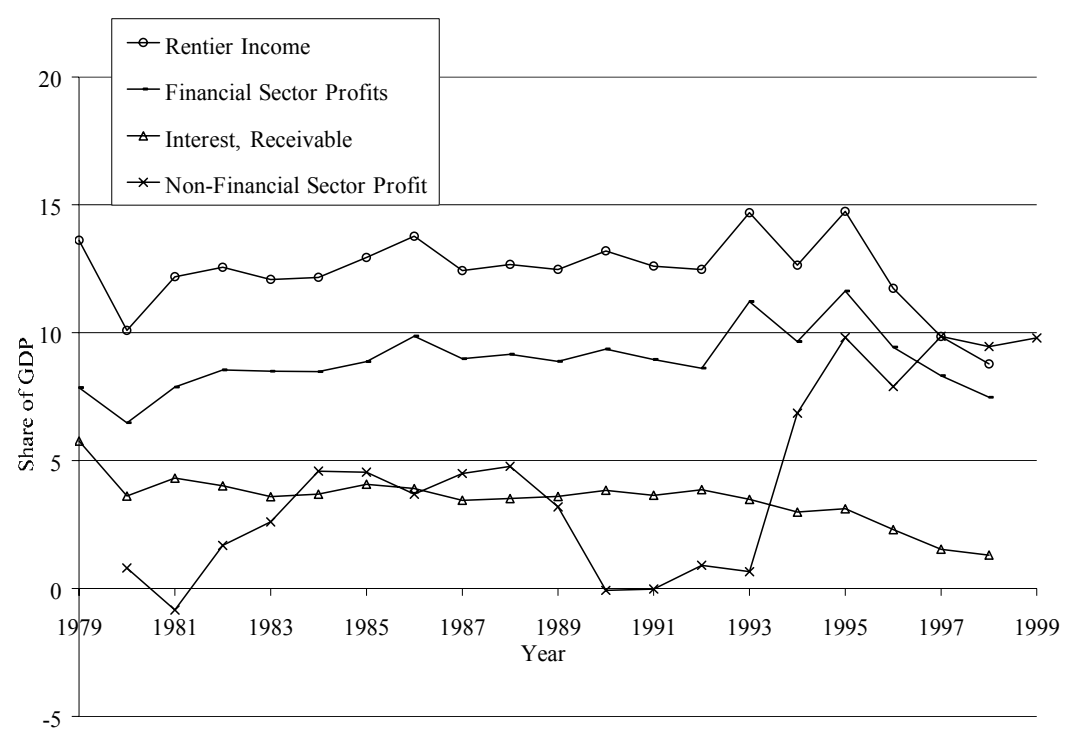

Figure 6: Components of Rentier Income Share and Non-Financial Sector Profit Share: United Kingdom 1968-2000

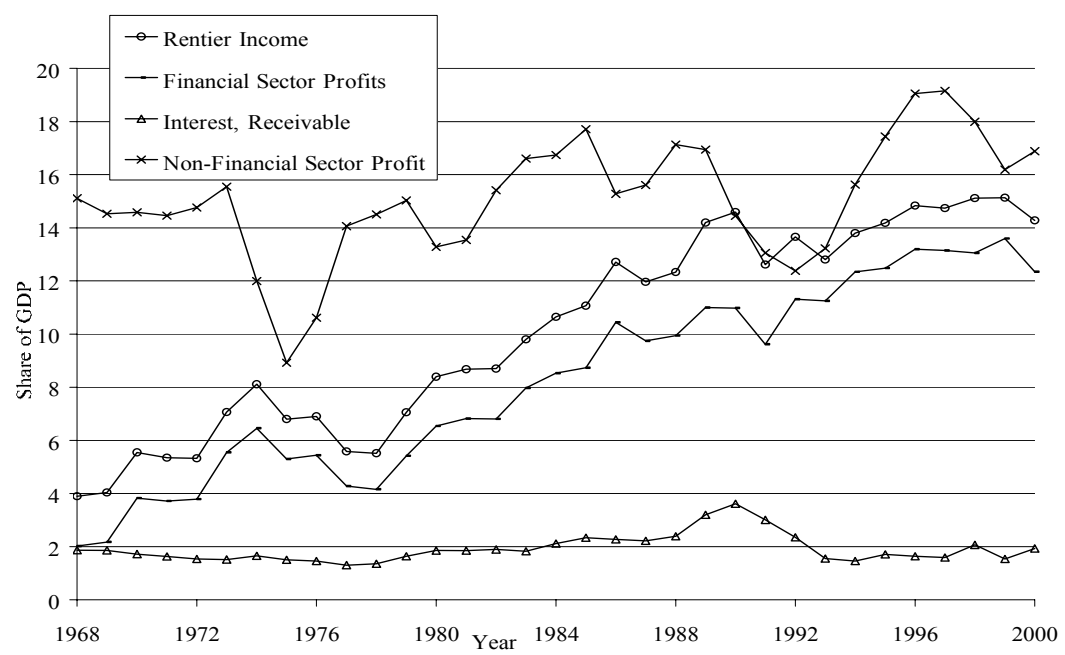


Figure 7: Components of Rentier Income Share and Non-Financial Sector Profit Share: United States 1960-1999

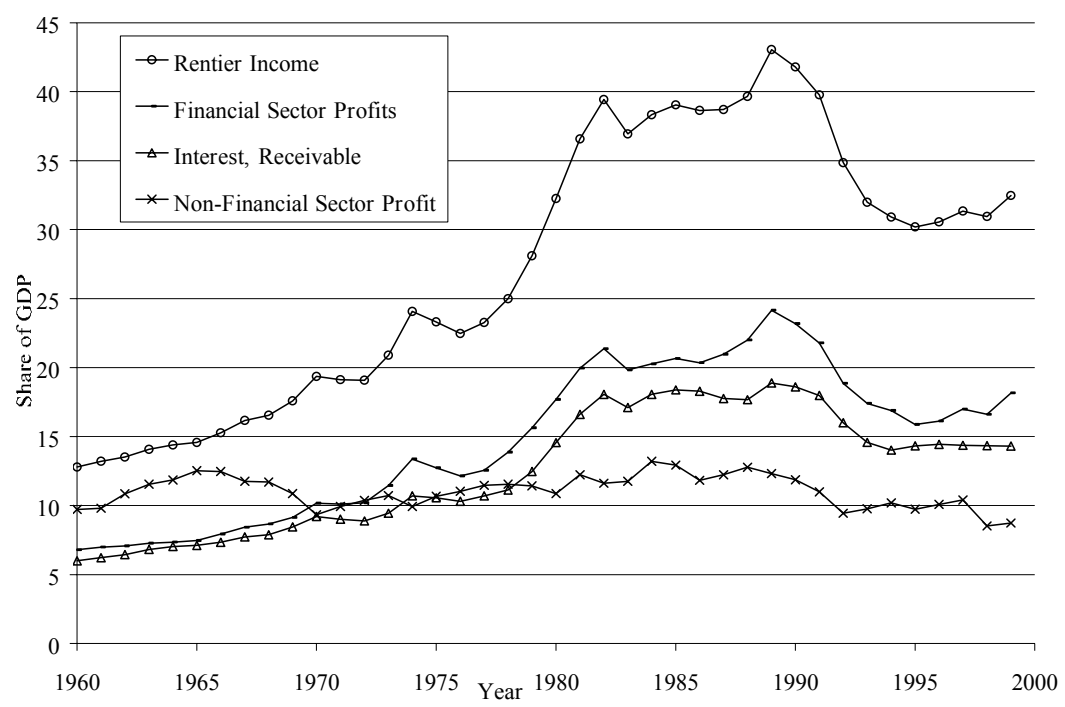

Figure 8: Components of Rentier Income Share and Non-Financial Sector Profit Share: Korea 1975-1999

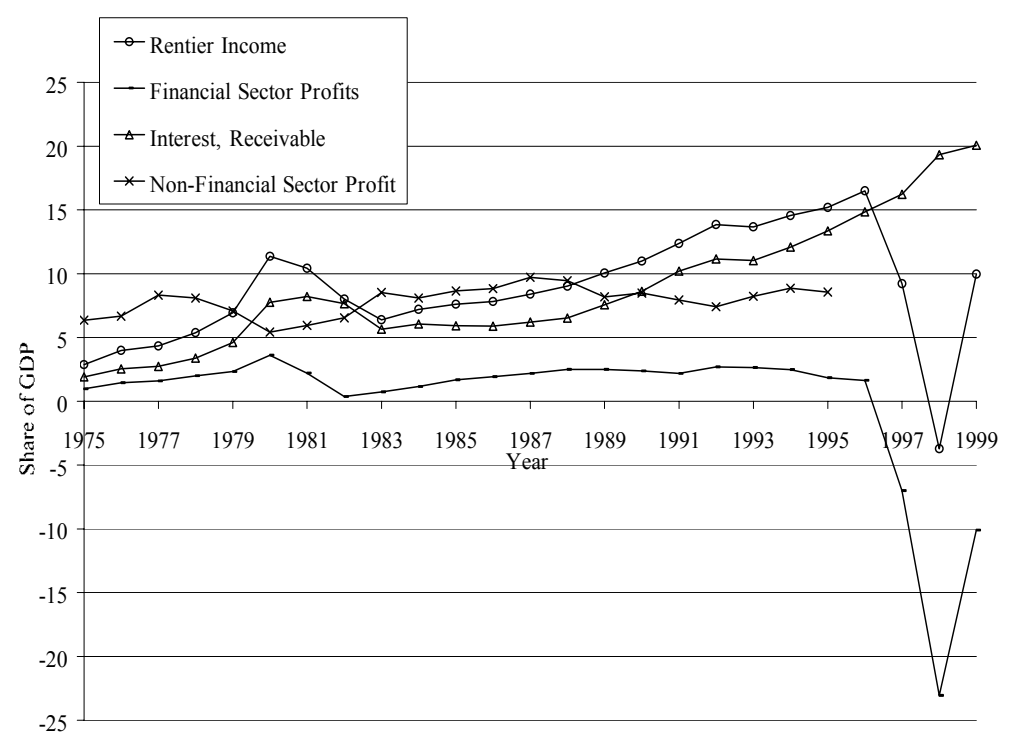


Figure 9: Components of Rentier Income Share and Non-Financial Sector Profit Share: Mexico 1989-1999

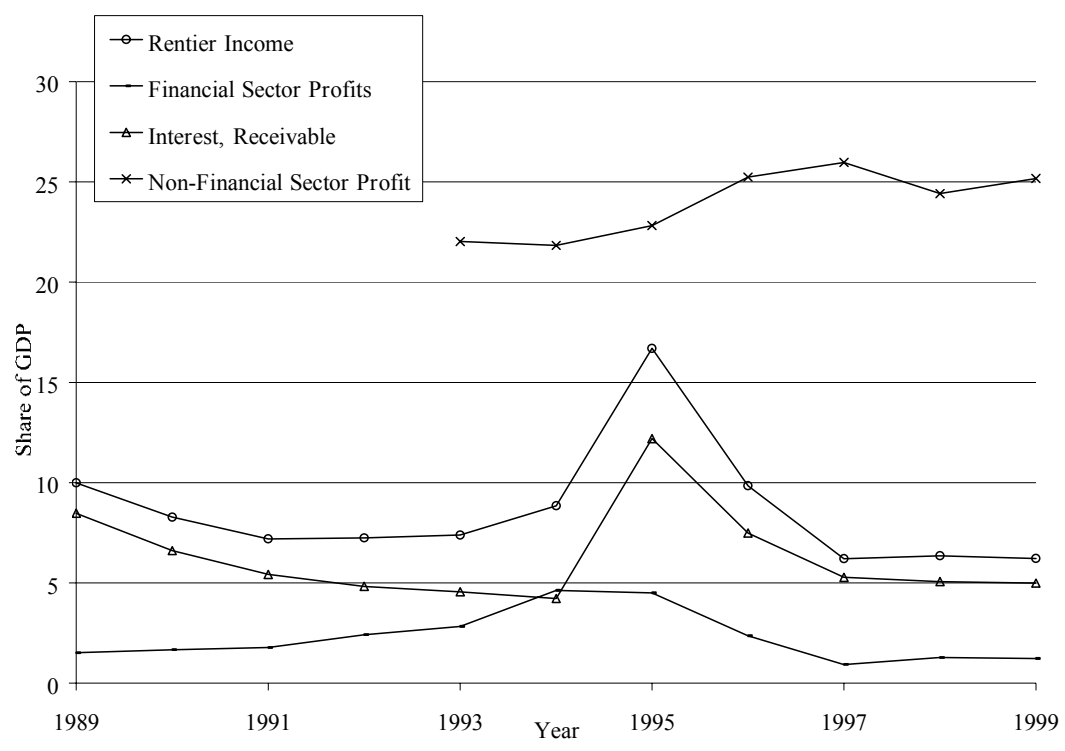

Figure 10: Rentier Income Share: Turkey 1983-1999

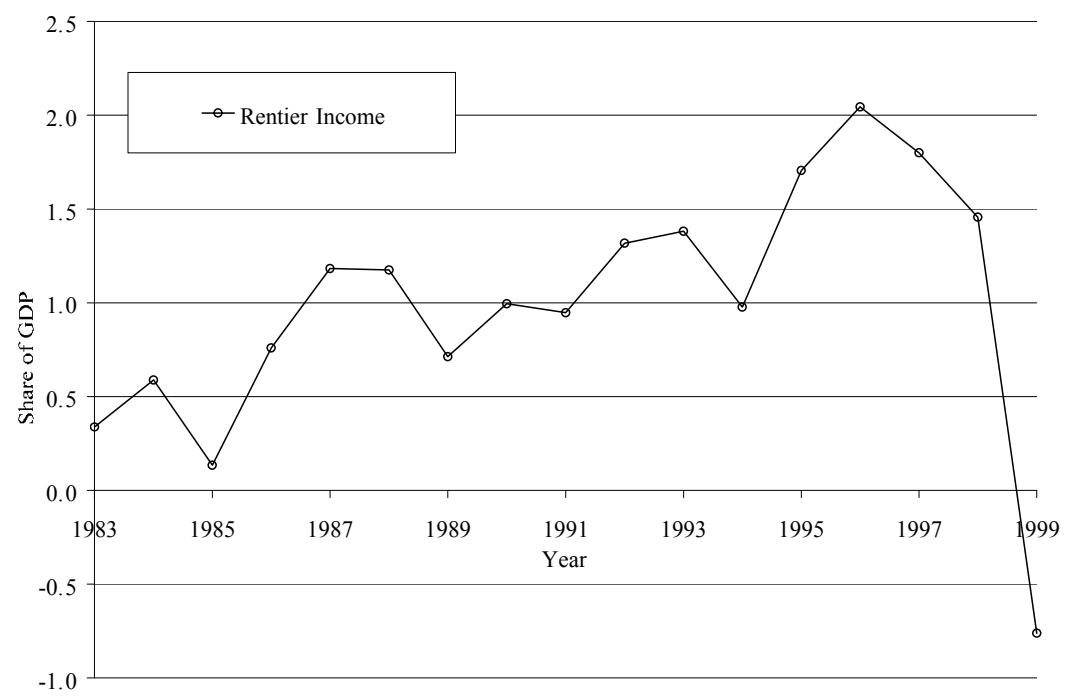


Figure 11: Capital Gains on Financial Assets in the United States Calculated Three Different Ways 1980-2000

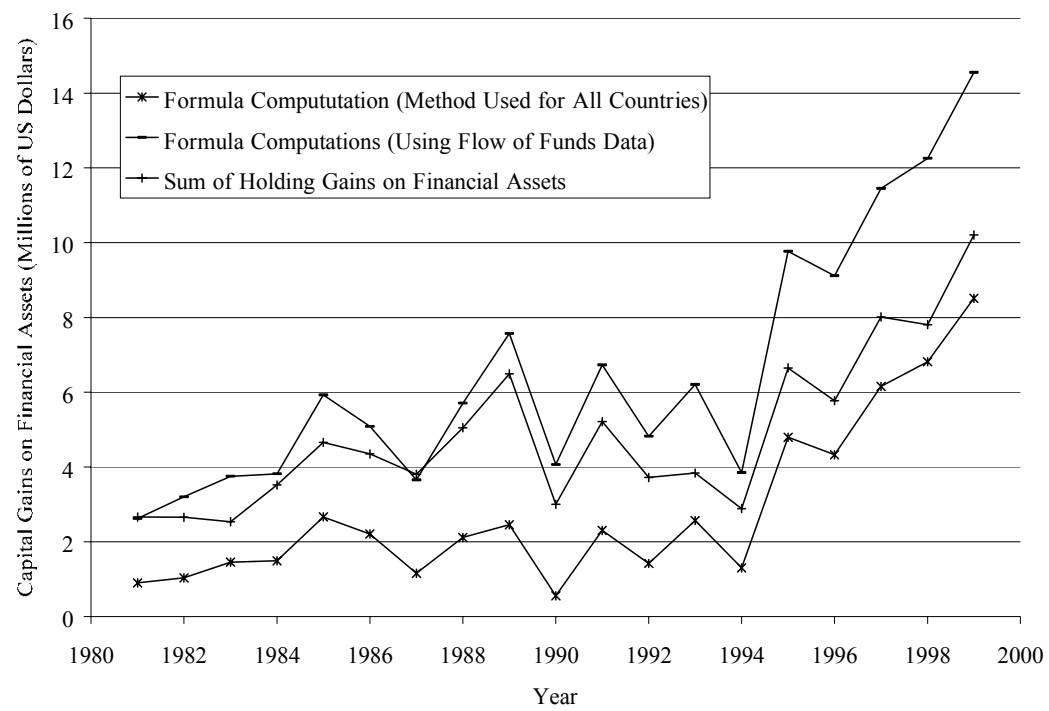

Figure 12: Rentier Income Share Calculated Using Two Measures of Capital Gains on Financial Assets: United States 1980-2000

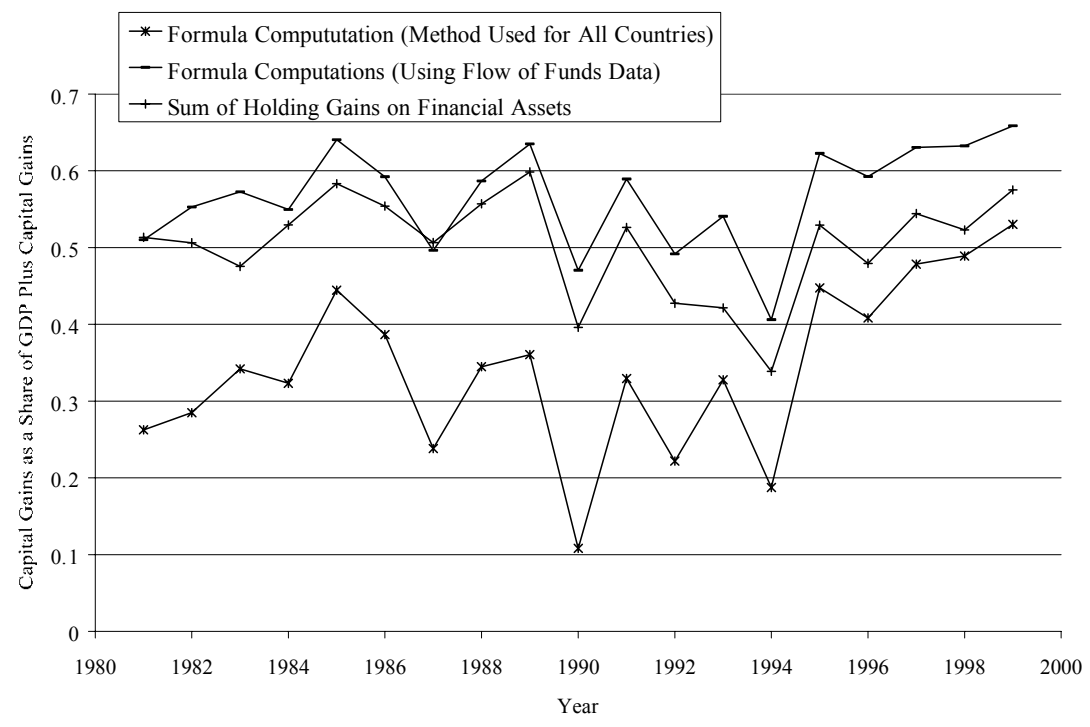




\section{DATA APPENDIX}

The data were constructed from the OECD National Accounts Vol. II 2001 and 1997 eds., OECD Bank Profitability: Financial Statements of Banks 2001 ed., and OECD Institutional Investors Yearbook 2001 ed. ${ }^{8}$ Financial sector profit data were taken from the National Accounts and from the Bank Profitability data. Interest receivable and GDP data were taken from the National Accounts. Data on capital gains data were taken from the Institutional Investors Yearbook. Rentier income is the sum of financial sector profits, interest receivable by all non-financial non-government resident institutional units, and capital gains on financial assets. Rentier income share is rentier income as a share of GDP. Data on non-financial sector profit share were taken from the National Accounts. These data have been included for comparison with the financial sector profit data. ${ }^{9}$ The inclusion of capital gains on financial assets is an issue for several reasons. Capital gains on financial assets are not included in GDP, which makes the calculation of rentier income share problematic. Thus we calculated the share as being rentier share plus capital gains as a share of GDP plus capital gains. Second, unrealized capital gains as well as realized capital gains on financial assets should be included. So our estimates attempted to include both.

\section{Estimates of Capital Gains}

With the exception of the U.S., we do not have data on capital gains. So we had to estimate these data for most countries. To estimate capital gains, we calculated the change in the value of financial assets in a given year, and subtracted the value of new issues of financial assets. However, we had to estimate new issues, as these data are not available.

We estimated capital gains according to the following formula.

(1) $C G=F A_{t}-F A_{t-1}-S_{t} * \frac{F A_{t}}{F A_{t}+K_{t}}$

where $\mathrm{CG}=$ capital gains on financial assets

$\mathrm{FA}=$ stock of financial assets

$\mathrm{S}=$ gross savings

$\mathrm{K}=$ gross capital stock

To calculate the rentier share with capital gains we divided rentier income plus capital gains by GDP plus capital gains.

\footnotetext{
${ }^{8}$ Organization for Economic Co-operation and Development (OECD), National Accounts Volume II: Detailed Tables, (Paris: OECD, 2001); OECD, National Accounts Volume II: Detailed Tables, (Paris: OECD, 1997); OECD, Bank Profitability: Financial Statements of Banks, (Paris: OECD, 2001); OECD, Institutional Investors Yearbook, (Paris: OECD, 2001).

${ }^{9}$ See Power, Epstein and Abrena, 2003, for more details on sources and methods of data construction.
} 


\section{REFERENCES}

Akyuz, Yilmaz and Korkut Boratav, 2001. "The Making of the Turkish Financial Crisis" http://www.umass.edu/peri/finagenda.html\#alphalist.

Baker, Dean, Gerald Epstein and Robert Pollin. eds. 1998. Globalization and Progressive Economic Policy. New York: Cambridge University Press.

Baker, Dean, Gerald Epstein and Robert Pollin, "Introduction", in Baker, Epstein and Pollin, 1998. Globalization and Progressive Economic Policy, pp. 1-34.

Blanchard, Olivier. 1997. The Medium Run. Brookings Papers on Economic Activity, 2. pp. 89158.

Boratav, Korkut and Erinc Yeldan. 2001. Turkey, 1980 - 2000: Financial Liberalization, Macroeconomic Instability and Patterns of Distribution. Wider.

Crotty, James and Gary Dymski. 2000. Can the Neoliberal Regime Survive Victory in Asia? The Political Economy of the Asian Crisis. http://www.umass.edu/peri/

Crotty, James and Gerald Epstein, 1996. "In Defense of Capital Controls". Socialist Register. pp. 118-149.

Crotty, James. 2002. The Effects of Financialization and Increased Competition on the Performance of Nonfinancial Corporations in the Neoliberal Era, mimeo, Political Economy Research Institute (PERI), University of Massachusetts, Amherst.

Diwan, Ishac. 2001. Debt as Sweat: Labor, Financial Crises and the Globalization of Capital. mimeo, IMF.

Dumenil, Gerard and Dominique Levy, 2001. "Costs and Benefits of Neo-liberalism: A Class Analysis". http://www.umass.edu/peri/finagenda.html\#alphalist.

Economy and Society, 2000. Special issue on "Financialization".

Epstein, Gerald. 1981. "Monetary in the Hidden Election", in Thomas Ferguson and Joel Rogers, The Hidden Election. New York: Pantheon Press.

Epstein, Gerald. 2001. "Financialization, Rentier Interests and Central Bank Policy", http://www.umass.edu/peri/finagenda.html\#alphalist.

Felix, David. 2001. "Why International Capital Mobility Should Be Curbed and How it Could be Done". http://www.umass.edu/peri/finagenda.html\#alphalist. 
Gosh, Jayati and C.P. Chandrasekhar 2001. Crisis As Conquest: Learning From East Asia New Delhi, India: Orient Longman Publisher.

Gosh, Jayati and C.P. Chandrasekhar, 2003. eds. Work and Well-Being in the Age of Finance. New Delhi: Tulika Books.

Harrison, Ann E. 2002. Has Globalization Eroded Labor's Share? Some Cross Country Evidence. mimeo. University of California, Berkeley.

Helleiner. Eric. 1994. States and the Resurgence of Global Finance: From Bretton Woods to the 1990's. Cornell University Press.

Jomo, K.S., ed. 2001. Malaysian Eclipse: Economic Crisis and Recovery, Jomo, K.S., ed., London and New York: Zed Books, 2001.

Kalecki, Michal. 1990. Political Aspects of Full Employment. in J. Osiantynski, ed., Collected Works of Michal Kalecki. Vol. 1. Oxford: Oxford University Press.

Krippner, Greta. 2002. "What is Financialization", mimeo, Department of Sociology, University of Wisconsin.

Lazonick, William and Mary O'Sullivan, eds. 2002. Corporate Governance and Sustainable Prosperity. New York: Palgrave.

Palma, Gabriel, 2000. The Three Routes to Financial Crises: The need for Capital Controls. Center for Economic Policy Analysis. www.newschool.edu/cepa.

Patnaik, Prabhat. 2003. Money, Finance and Contradictions of Capitalism. in Ghosh and Chandrasekhar, Work and Well-Being in the Age of Global Finance.

Pollin, Robert N. 2003. The Contours of Descent: U.S. Economic Fractures and the Landscape of Global Austerity. London: Verso Press.

Pollin, Robert N. 2001. "Globalization, Inequality and Financial Instability: Confronting the Marx, Keynes and Polanyi Problems in Advanced Capitalist Economies." http://www.umass.edu/peri/finagenda.html\#alphalist

Power, Dorothy, Gerald Epstein and Matthew Abrena, 2002. Trends in Rentier Incomes in OECD Countries: Estimates, Data, and Methods. mimeo. Political Economy Research Institute (PERI), University of Massachusetts, Amherst.

Stiglitz, Joseph. E. 2002. Globalization and Its Discontents.

Taylor, Lance and Ute Pieper, 1998. "The Revival of the Liberal Creed: the IMF, the World Bank, and Inequality in A Globalized Economy", in Baker, Epstein and Pollin, eds. Globalization and Progressive Economic Policy, pp. 37-64. 
Taylor Lance, ed. 2001. External Liberalization, Economic Performance and Social Policy. New York: Oxford University Press.

Yeldan, A. Erinc, 2000. "The Impact of Financial Liberalization and The Rise of Financial Rents on Income Inequality; The Case of Turkey", WIDER. 